\title{
Enhancement of Productivity, Profitability and Resource Use Efficiency of Rice-rapeseed Cropping System through Liming, Planting Time and Tillage Practices in North East India
}

\author{
Sakhen Sorokhaibam ${ }^{1 *}$, N. Anando Singh ${ }^{2}$ and L. Nabachandra ${ }^{3}$ \\ ${ }^{1}$ Krishi Vigyan Kendra, Bishnupur District, Manipur (795 134), India \\ ${ }^{2}$ AICRP on Chickpea, Directorate of Research, Central Agricultural University, Imphal (795 004), India \\ ${ }^{3}$ Department of Agronomy, College of Agriculture, CAU, Imphal, Manipur (795 004), India
}

\section{Article History}

Manuscript No. AR1606

Received in $30^{\text {th }}$ May, 2016

Received in revised form $6^{\text {th }}$ June, 2016

Accepted in final form $7^{\text {th }}$ June, 2016

\section{Correspondence to}

"E-mail: sakhensorokhaibam@gmail.com

\section{Keywords}

Liming, planting time, rice-rapeseed, system productivity, tillage

\begin{abstract}
Field experiments were conducted during 2010-12 to study the effect of liming, planting time and tillage on system productivity, profitability and resource use efficiency of rice (Oryza sativa L.) - rapeseed (Brassica campestris L.var. toria) cropping system. The experiment was laid out in a split plot design with two factors i.e. liming (liming and no liming) and planting time (early and normal) given to rice crop during rainy (kharif) season in the main plots and 2 tillage practices (no tillage and conventional tillage) given to succeeding rapeseed during the winter ( $r a b i$ ) season in sub-plots. Application of lime @ $500 \mathrm{~kg} \mathrm{CaCO}_{3}$ ha $^{-1}$ before planting rice continuously for two cropping seasons had residual effect on seed and stover yields of succeeding rapeseed resulting in improvement of system productivity in terms of rice equivalent yield (REY), production efficiency (PE) and water use efficiency (WUE) by $7.2 \%$, $7.4 \%$ and $11.1 \%$, respectively over no liming. Liming failed to increase $\mathrm{B}: \mathrm{C}$ ratio but enhanced energy productivity by $3.7 \%$ over no liming. Early planting of rice 15 days ahead of normal planting time enhanced growth and yield of rapeseed crop and had registered significantly higher REY, land use efficiency (LUE), PE, WUE, NPK nutrient use efficiencies, net returns and energy use efficiency compared to normal planting. No tillage (NT) enhanced REY, NPK use efficiencies, WUE and B:C ratio of the system. NT was the most energy efficient practice with $14.6 \%$ less energy requirement as compared to conventional tillage $(\mathrm{CT})$.
\end{abstract}

\section{Introduction}

Rice, the principal food crop of the North East India, accounts more than $80 \%$ of the total cultivated area of the region and $7.8 \%$ of total rice area in India, whereas its share in national rice production is meagre (Yadav et al. 2013). The average productivity of rice in the region is very low $\left(1.6 \mathrm{t} \mathrm{ha}^{-1}\right)$ compared to national averages, leading to about $1.77 \mathrm{mt}$ deficit of rice (Tomar and Das, 2011). Though in the region, a sizeable portion particularly lowland rice areas in valley land, is able to support a good second crop with carryover residual soil moisture (due to heavy texture and high moisture retention after long term submergence for low land rice), it is mostly mono-cropped and most of the farmers get employment only during rice season and remain idle during rest part of the year. In some areas, farmers grow second crops by broadcasting the seeds within the standing rice crop (first crop) in well-moistened soils without any tillage at 15-20 days prior to the harvest of rice. Under this system of growing crops without tillage also called as relay cropping, farmers obtain much less yield $\left(0.2-0.3 \mathrm{t} \mathrm{ha}^{-1}\right)$ from second crops. It might be due to unfavourable physical conditions of the soil which inhibit growth and nutrient uptake of the crops in rice fallow. These yields do not provide adequate returns to the farmer, so that low land rice soils, in particular rainfed low land rice soils, represent an underutilised resource during the dry winter (rabi) season. Thus, this aged old mono-crop system has forced the farm community to live in abject poverty. The need of the hour is, therefore, to intensify agricultural production through increasing the cropping intensity which can be achieved through rice-based cropping system, as the rice being the main crop of the region. Inclusion of pulses, oilseeds and vegetables in the system was found more beneficial than cereals after cereals (Kumpawat, 
2001; Raskar and Bhoi, 2001).

Productivity and profitability from second crops in rice fallow can be improved with suitable crop management technique even by utilizing residual soil moisture (Pratibha et al.,1996; Mahata et al., 1992; Kar et al., 2004). Soil acidity may not create any problem for the growth and productivity of rice due to water stagnation during growth and nature of the crop. Since rice is being cultivated predominantly as mono crop, neutralization of acidity by liming was not given priority in the past. However, advocacy of growing vegetables, oil seeds and pulses into rice fallow land would certainly require management of acidity to raise productivity and profitability.

The puddled conditions of the soil are a major cause of the poor establishment and performance of secondary crops after rice (Syarifuddin, 1979). Yields are also limited by nutritional and biological constraints. To increase the utilisation of these soils, improved management practices are required to enable dry season crops to use the stored water in the soil profile after the rice crop. The importance of managing rice cultivation to facilitate rabi cropping and to increase total system productivity has been well recognised. The one management option in this regard is time scheduling like early sowing of rice, if possible. The pulses and oilseeds fit in such a condition without much disruption of kharif cereal production system. As such pulses and oilseed crops are ideal crops that can occupy the area vacated by kharif rice. In view of the above, the study was carried out to explore the possibility of growing rapeseed after kharif rice and to improve sustainability of rice production system besides enhancing production and augmenting income in rainfed rice fallow system.

\section{Materials and Methods}

A field experiment was conducted in a sub tropical climate of Imphal Valley during kharif and rabi seasons for two consecutive years 2010-11 and 2011-12 at the experimental field of College of Agriculture, Central Agricultural University, Iroisemba, Imphal situated at $24^{\circ} 46^{\prime} \mathrm{N}$ latitude and $93^{\circ} 54^{\prime} \mathrm{E}$ longitude with an average altitude of 774.5 meter above the mean sea level. The soil of the experimental site was clayey in texture, strongly acidic in reaction $(\mathrm{pH} 5.2)$, high in organic carbon (18.5 $\mathrm{g} \mathrm{kg}^{-1}$ ) medium in available $\mathrm{N}\left(442.0 \mathrm{~kg} \mathrm{ha}^{-1}\right)$, low in $\mathrm{P}\left(10.6 \mathrm{~kg} \mathrm{ha}^{-1}\right)$ and high in $\mathrm{K}\left(214.9 \mathrm{~kg} \mathrm{ha}^{-1}\right)$. The total rainfall received during 2010-11 and 2011-12 cropping seasons varied from 1115.7-1320.2 $\mathrm{mm}$ and 1175.5-1220.8 $\mathrm{mm}$, respectively. The experiment was conducted on ricerapeseed cropping system in split plot design with four factorial combinations of liming (liming and no liming) and planting time (early and normal) treatments given to rice during kharif season in main plots and two tillage practices (no tillage and conventional tillage) before rabi rapeseed crop in sub plots with four replications. Cost effective liming@ @ $500 \mathrm{~kg} \mathrm{ha}^{-1}$ in the form of powdered lime stone was added annually 25 days before transplanting rice to liming treatment. 'Leimaphou (K.D. 2-6-3)' rice and 'M-27' rapeseed were grown as test crops. Rice was sown on 20 May (early) and 7 June (normal) and twenty seven days old seedlings were transplanted with $2 / 3$ seedlings hill $^{-1}$ at $20 \times 10 \mathrm{~cm}^{2}$ spacing. The succeeding rapeseed crop was sown on $15^{\text {th }}$ October and $22^{\text {nd }}$ October for early planted rice followed by no tillage and conventional tillage respectively and $30^{\text {th }}$ October and $6^{\text {th }}$ November for normal planted rice followed by no tillage and conventional tillage respectively. In no tillage plot, rabi crop seeds were broadcasted onto untilled soil, but in conventional tillage plots, two harrowing were done and then followed by planking. A common dose of NPK@ $@ 60: 17.2: 24.9 \mathrm{~kg} \mathrm{ha}^{-1}$ in the forms of urea, single super phosphate and muriate of potash respectively was applied to rice. For conventional tillage of rapeseed, the recommended NPK dose of 40:8.6:16.6 $\mathrm{kg} \mathrm{ha}^{-1}$ was applied and in case of no tillage plots, only N@20 kg ha-1 was applied. The data on growth and yield, oil content, plant N, P and K contents of the component crops were recorded following standard procedures. The total nutrient uptakes were calculated by multiplying plant NPK contents with respective dry weights. Water use efficiency (WUE) was calculated based on grain/
$\mathrm{WUE}=\frac{\mathrm{Y}}{\mathrm{ET}_{\text {crop }}} \quad \begin{aligned} & \text { seed yield and Evapotranspiration }(\mathrm{ET}) \mathrm{as} \text { : } \\ & \text { where, WUE=water use efficiency, } \mathrm{kg}\end{aligned}$ ha- $\mathrm{mm}^{-1}, \mathrm{Y}=$ yield of grain or seed, $\mathrm{kg} \mathrm{ha}^{-1}$

and ET crop=cumulative crop evapotranspiration, $\mathrm{mm}$. ET was estimated by following Pan Evaporation method.

The Partial factor productivity (PFP) and system productivity expressed as: Rice equivalent yield (REY) were also calculated as :

$$
\begin{aligned}
& \mathrm{PFP}(\mathrm{NPK})=\frac{\text { Grain yield }(\mathrm{kg})}{\mathrm{kg}\left(\mathrm{N}+\mathrm{P}_{2} \mathrm{O}_{5}+\mathrm{K}_{2} \mathrm{O}\right) \text { applied }} \quad \text { and } \\
& \mathrm{REY}=\mathrm{Y}_{\text {rice }}+\frac{\mathrm{Y}_{\text {rapeseed }} \times \mathrm{P}_{\text {rapeseed }}}{\mathrm{P}_{\text {rice }}}
\end{aligned}
$$

where, $\mathrm{Y}=$ yield of grain or seed, tonnes $\mathrm{ha}^{-1}$ and $\mathrm{P}=$ price for grain or seed, $₹ \mathrm{t}^{-1}$. Production efficiency in terms of $\mathrm{kg} \mathrm{ha}^{-1}$ day $^{-1}$ was calculated from the rice equivalent yield value of the system divided by the total duration of crops in the sequence. Crop intensification was measured by calculating land utilization efficiency by dividing the total duration of respective cropping system by the number of days in a year (365 days) and expressed in percentage. The cost of cultivation, gross return, net return (gross return-cost of cultivation) and benefit cost ratio (gross return/cost of cultivation) were calculated on the basis of prevailing market price of different inputs and outputs. Energy input was estimated in Mega Joule (MJ) ha ${ }^{-1}$ with reference to the standard values prescribed by Mittal et 
al. (1985). Based on the energy equivalents of the inputs and output, energy use efficiency, energy productivity, energy intensity in physical terms and energy intensity in economic terms were calculated.

Energy use efficiency $=$ Gross energy output $\left(\mathrm{MJ} \mathrm{ha}^{-1}\right) /$ Energy input $\left(\mathrm{MJ} \mathrm{ha}^{-1}\right)$, Energy productivity $\left(\mathrm{kg} \mathrm{MJ}^{-1}\right)=[$ Total output (grain+straw) $\left.\left(\mathrm{kg} \mathrm{ha}^{-1}\right)\right] /$ Total energy input $\left(\mathrm{MJ} \mathrm{ha}^{-1}\right)$, Net energy output $\left(\mathrm{MJ} \mathrm{ha}^{-1}\right)=$ Gross energy output $\left(\mathrm{MJ} \mathrm{ha}^{-1}\right)$-Energy input $\left(\mathrm{MJ} \mathrm{ha}^{-1}\right)$, Energy intensity in physical terms $\left(\mathrm{MJ} \mathrm{kg}^{-1}\right)$ $=$ Total energy input $\left(\mathrm{MJ} \mathrm{ha}^{-1}\right) /$ Total output $($ grain + straw $)(\mathrm{kg}$ $\left.\mathrm{ha}^{-1}\right)$, Energy intensity in economic terms $\left(\mathrm{MJ} \mathrm{J}^{-1}\right)=$ Gross energy output $\left(\mathrm{MJ} \mathrm{ha}^{-1}\right) /$ Cost of cultivation (₹ ha $\left.{ }^{-1}\right)$.

Data collected on different parameters were subjected to statistical analysis by using MSTAT C package in computer, where the significance of different main effects of the treatments involved were tested with 'F-test' and the critical difference (CD) values at $5 \%$ level of significance were calculated for the effects which were found significant at least at 5 per cent level of significance.

\section{Results and Discussion}

\subsection{Residual effect of liming on rapeseed}

Residual effect of lime on rapeseed as rabi crop after rice was not significant on growth attributes such as plant height, number of branches plant ${ }^{-1}$ and dry matter production of plant (Table 1). However, marginal increases in plant height

Table 1: Growth, yield attributes and yield of rapeseed as influenced by liming and planting time to rice and tillage practices to rapeseed

\begin{tabular}{|c|c|c|c|c|c|c|c|c|c|c|c|c|c|c|c|c|c|c|}
\hline \multirow[t]{2}{*}{$\begin{array}{l}\text { Treat- } \\
\text { ments }\end{array}$} & \multicolumn{2}{|c|}{$\begin{array}{l}\mathrm{PH} \\
(\mathrm{cm})\end{array}$} & \multicolumn{2}{|c|}{$\mathrm{BP}$} & \multicolumn{2}{|c|}{$\begin{array}{c}\text { DM } \\
\left(\text { g plant }^{-1}\right)\end{array}$} & \multicolumn{2}{|c|}{ SP } & \multicolumn{2}{|c|}{ SS } & \multicolumn{2}{|c|}{ TW $(g)$} & \multicolumn{2}{|c|}{$\begin{array}{c}\text { SY } \\
\left(\mathrm{t} \mathrm{ha}^{-1}\right)\end{array}$} & \multicolumn{2}{|c|}{$\begin{array}{c}\text { SY } \\
\left(\mathrm{t} \mathrm{ha}^{-1}\right)\end{array}$} & \multicolumn{2}{|c|}{ HI } \\
\hline & $\bar{\Xi}$ & $\stackrel{\text { ㄱ}}{\stackrel{\text { }}{2}}$ & $\bar{\Xi}$ & 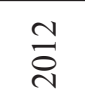 & $\overline{\vec{i}}$ & $\stackrel{\sim}{\stackrel{\sim}{*}}$ & $\bar{\Xi}$ & $\stackrel{\sim}{\stackrel{2}{\sim}}$ & $\overrightarrow{\text { స }}$ & $\stackrel{\sim}{\stackrel{2}{~}}$ & $\overline{\vec{~}}$ & $\stackrel{\sim}{\stackrel{2}{2}}$ & $\overline{\vec{\lambda}}$ & $\stackrel{\sim}{\stackrel{\sim}{*}}$ & $\overline{\vec{~}}$ & $\stackrel{\sim}{\stackrel{\overbrace{}}{~}}$ & $\overline{\vec{~}}$ & $\stackrel{\sim}{\stackrel{\sim}{2}}$ \\
\hline \multicolumn{19}{|l|}{ Liming } \\
\hline NL & 37.7 & 44.8 & 5.2 & 5.8 & 2.9 & 4.1 & 19.1 & 22.0 & 9.7 & 12.4 & 2.5 & 2.5 & 0.50 & 0.52 & 1.08 & 1.05 & 31.3 & 33.3 \\
\hline $\mathrm{L}$ & 39.6 & 46.3 & 5.6 & 6.2 & 2.9 & 4.0 & 21.1 & 26.4 & 10.5 & 13.3 & 2.4 & 2.6 & 0.55 & 0.59 & 1.13 & 1.21 & 33.0 & 32.8 \\
\hline $\begin{array}{l}\text { SEm } \\
\pm\end{array}$ & 1.36 & 1.13 & 0.09 & 0.22 & 0.01 & 0.03 & 0.60 & 0.77 & 0.30 & 0.36 & 0.07 & 0.05 & 0.02 & 0.02 & 0.06 & 0.03 & 1.68 & 1.21 \\
\hline $\begin{array}{l}\mathrm{CD} \\
(p= \\
0.05)\end{array}$ & NS & NS & 0.31 & NS & NS & NS & 2.08 & 2.66 & NS & NS & NS & NS & NS & 0.07 & NS & 1.00 & NS & NS \\
\hline \multicolumn{19}{|c|}{ Planting Time } \\
\hline Early & 39.0 & 45.5 & 5.7 & 6.5 & 2.9 & 3.8 & 20.4 & 24.8 & 10.5 & 13.4 & 2.6 & 2.5 & 0.57 & 0.55 & 1.23 & 1.20 & 31.6 & 31.9 \\
\hline $\begin{array}{l}\text { Nor- } \\
\text { mal }\end{array}$ & 38.3 & 45.5 & 5.1 & 5.6 & 2.9 & 4.2 & 19.6 & 23.6 & 9.7 & 12.3 & 2.3 & 2.5 & 0.48 & 0.55 & 0.98 & 1.07 & 32.6 & 34.1 \\
\hline $\begin{array}{l}\text { SEm } \\
\pm\end{array}$ & 1.36 & 1.13 & 0.09 & 0.22 & 0.01 & 0.03 & 0.60 & 0.77 & 0.30 & 0.36 & 0.07 & 0.05 & 0.02 & 0.02 & 0.06 & 0.03 & 1.68 & 1.21 \\
\hline $\begin{array}{l}\mathrm{CD} \\
(p= \\
0.05)\end{array}$ & NS & NS & 0.31 & 0.76 & NS & NS & NS & NS & NS & NS & 0.24 & NS & 0.07 & NS & 0.21 & 0.10 & NS & NS \\
\hline Tillage & & & & & & & & & & & & & & & & & & \\
\hline $\mathrm{NT}^{\#}$ & 37.9 & 47.1 & 5.5 & 5.6 & 2.8 & 3.9 & 18.5 & 22.6 & 10.1 & 12.2 & 2.6 & 2.5 & 0.49 & 0.53 & 0.98 & 1.04 & 31.7 & 33.9 \\
\hline $\mathrm{CT}^{*}$ & 39.4 & 43.9 & 5.3 & 6.4 & 3.0 & 4.1 & 21.6 & 25.8 & 10.1 & 13.6 & 2.3 & 2.6 & 0.56 & 0.57 & 1.03 & 1.22 & 32.6 & 32.1 \\
\hline $\begin{array}{l}\text { SEm } \\
\pm\end{array}$ & 0.54 & 0.49 & 0.03 & 0.21 & 0.01 & 0.03 & 0.63 & 0.73 & 0.32 & 0.35 & 0.07 & 0.04 & 0.02 & 0.02 & 0.05 & 0.05 & 1.78 & 0.64 \\
\hline $\begin{array}{l}\mathrm{CD} \\
(p= \\
0.05)\end{array}$ & NS & 1.60 & 0.10 & 0.68 & NS & NS & 2.05 & 2.38 & NS & 1.14 & 0.23 & 0.13 & 0.06 & NS & 0.15 & 0.15 & NS & NS \\
\hline
\end{tabular}

${ }^{\#}$ NT: No tillage; ${ }^{*}$ CT: Conventional tillage; PH: Plant height; BP: Branches plant ${ }^{-1}$; DM: Dry matter; SP: Siliqua plant ${ }^{-1}$; SS: Seeds siliqua ${ }^{-1}$; TW: Test weight; SY: Seed yield; HI: Harvest Index 
(3.3\%) and number of branches plant ${ }^{-1}(6.9 \%)$ due to liming were observed during second year of the study, though these parameters were not significant statistically. Positive influence of residual effect of liming could be noted on yield attributes of rapeseed such as number of siliqua plant ${ }^{-1}$ and number of seeds siliqua ${ }^{-1}$ but not on the 1000 -seed weight during both the years of field study. There were $10.5 \%$ and $20.0 \%$ significant increments in number of siliqua plant ${ }^{-1}$ during $2010-11$ and 2011-12 respectively. The increases in the number of seeds siliqua ${ }^{-1}$ were 8.2 and $7.3 \%$ respectively during $2010-11$ and 2011-12. However, these increments were not significant statistically. As yield attributes are directly related to seed yield of the crop, there were $10 \%$ and $13.5 \%$ increments in the seed yield of rapeseed under liming treatment over no liming during first year and second year respectively. Increased stover yield of rapeseed due to liming in both the years could be attributed to increased plant height and branches/plant, though the effect is not much perceptible in the plant dry matter production. Significant increase in oil yield of rapeseed (Table 2) in second year due to liming could be related to the increase in seed yield only as there was no significant improvement in seed oil content of rapeseed due to application of lime. Liming did not result significant increase in $\mathrm{N}$ uptake, but it did increase $\mathrm{P}$ and $\mathrm{K}$ uptake by the crop during both the years of study which can be attributed to increased seed and stover yields and increased $\mathrm{P}$ and $\mathrm{K}$ content in seed and stover under the treatment. The increase in P uptake due to liming may be due to fact, that it breaks the $\mathrm{Fe}$ and $\mathrm{Al}$ phosphates in soil, thereby making $\mathrm{P}$ available to plant. There are reports on increased uptake of nitrogen (Bishnoi, 1994), phosphorus (Datta and Gupta,

Table 2: Oil content and yield, total nutrient uptake and water use efficiency of rapeseed as influenced by liming and planting time to rice and tillage practices to rapeseed

\begin{tabular}{|c|c|c|c|c|c|c|c|c|c|c|c|c|}
\hline \multirow[t]{2}{*}{ Treatments } & \multicolumn{2}{|c|}{$\begin{array}{c}\text { Oil content } \\
(\%)\end{array}$} & \multicolumn{2}{|c|}{$\begin{array}{l}\text { Oil yield } \\
\left(\mathrm{kg} \mathrm{ha}^{-1}\right)\end{array}$} & \multicolumn{2}{|c|}{$\begin{array}{l}\text { Total } \mathrm{N} \text { uptake } \\
\left(\mathrm{kg} \mathrm{ha}^{-1}\right)\end{array}$} & \multicolumn{2}{|c|}{$\begin{array}{l}\text { Total P uptake } \\
\left(\mathrm{kg} \mathrm{ha}^{-1}\right)\end{array}$} & \multicolumn{2}{|c|}{$\begin{array}{l}\text { Total K uptake } \\
\quad\left(\mathrm{kg} \mathrm{ha}^{-1}\right)\end{array}$} & \multicolumn{2}{|c|}{$\begin{array}{l}\text { Water use efficiency } \\
\qquad\left(\mathrm{kg} \mathrm{ha}^{-1} \mathrm{~mm}\right)\end{array}$} \\
\hline & 2011 & 2012 & 2011 & 2012 & 2011 & 2012 & 2011 & 2012 & 2011 & 2012 & 2011 & 2012 \\
\hline \multicolumn{13}{|l|}{ Liming } \\
\hline No liming & 38.0 & 35.2 & 190 & 182 & 14.9 & 18.6 & 2.4 & 2.8 & 11.6 & 9.6 & 5.6 & 6.9 \\
\hline Liming & 37.9 & 35.4 & 207 & 206 & 16.9 & 20.0 & 3.0 & 3.6 & 13.9 & 13.7 & 6.1 & 7.7 \\
\hline $\operatorname{SEm} \pm$ & 0.31 & 0.43 & 7 & 7 & 0.76 & 0.50 & 0.06 & 0.07 & 0.47 & 0.23 & 0.22 & 0.24 \\
\hline $\mathrm{CD}(p=0.05)$ & NS & NS & NS & 24 & NS & NS & 0.21 & 0.24 & 1.63 & 0.80 & NS & 0.83 \\
\hline \multicolumn{13}{|l|}{ Planting Time } \\
\hline Early & 38.5 & 36.9 & 218 & 186 & 17.2 & 20.4 & 3.2 & 3.5 & 14.3 & 13.1 & 6.4 & 7.1 \\
\hline Normal & 37.4 & 33.7 & 179 & 202 & 14.6 & 18.2 & 2.2 & 2.9 & 11.2 & 10.3 & 5.2 & 7.5 \\
\hline $\mathrm{SEm} \pm$ & 0.31 & 0.43 & 7 & 7 & 0.76 & 0.50 & 0.06 & 0.07 & 0.47 & 0.23 & 0.22 & 0.24 \\
\hline $\mathrm{CD}(p=0.05)$ & 1.07 & 1.49 & 24 & NS & NS & 1.73 & 0.21 & 0.24 & 1.63 & 0.80 & 0.76 & NS \\
\hline \multicolumn{13}{|l|}{ Tillage } \\
\hline $\mathrm{NT}^{\#}$ & 37.9 & 36.4 & 186 & 194 & 15.5 & 17.1 & 2.6 & 3.0 & 11.3 & 10.5 & 5.4 & 6.9 \\
\hline $\mathrm{CT}^{*}$ & 38.0 & 34.2 & 211 & 195 & 16.3 & 21.5 & 2.8 & 3.4 & 14.2 & 12.8 & 6.3 & 7.7 \\
\hline $\operatorname{SEm} \pm$ & 0.19 & 1.17 & 8 & 9 & 0.70 & 0.88 & 0.06 & 0.10 & 0.38 & 0.38 & 0.24 & 0.19 \\
\hline $\mathrm{CD}(p=0.05)$ & NS & NS & NS & NS & NS & 2.87 & NS & 0.33 & 1.24 & 1.24 & 0.78 & 0.62 \\
\hline
\end{tabular}

${ }^{\# N T}$ : No tillage; ${ }^{*} \mathrm{CT}$ : Conventional tillage

1984; Gupta and Sharma, 1985) and potassium (Ghosh and Mukhopadhyay, 2001) due to the application of lime to wide range of crops. Significantly higher WUE by the crop (Table 2 ) was recorded in second year because of significant increase in seed yield and less value of $\mathrm{ET}_{\text {crop }}$.

3.2. Effect of liming on the performance of rice-rapeseed cropping system

When the performance of the system was evaluated,it was evident that liming to rice crop improved system productivity in terms of rice equivalent yield (REY), production efficiency (PE), water use efficiency (WUE) and NPK nutrient use efficiencies. Application of liming led to $7.2 \%$ increase in system productivity (REY) and 7.4\% in PE over no liming, respectively. There were significant $11.1 \%$ increase in WUE, $7.3 \%$ increase in nitrogen use efficiency (NUE) and 7.2\% increase both for phosphorous use efficiency (PUE) and potassium use efficiency (KUE) in liming treatment over no liming (Table 3). Since liming treatment had resulted increase in grain yield of rice as well as seed yield of rapeseed, hence, 
REY was also increased. Since WUE and NPK use efficiencies were calculated based on the REY, their trends were also closely related to the REY.

\subsection{Effect of planting time on rapeseed}

The seed yield of rapeseed was increased by $18.8 \%$ under early planting over normal planting in 2010-11, but both the planting time treatments performed equally in terms of seed yield in the next year. The significant increase in seed yield of rapeseed under early planting in first year was contributed by the increase in yield attributes such as number of siliquae plant $^{-1}$, number of seeds siliqua ${ }^{-1}$ and 1000 -seed weight of which the latter contributed significantly (Table 1 ). The yield benefit due to early planting of rapeseed-mustard was also reported by Patel et al. (1980) and Yadav et al. (1994). Tripathi et al., (2008) reported that the yield and yield attributes of Indian mustard (Brassica juncea) decreased significantly with shift of sowing dates from October to November. Significant increase in stover yields of rapeseed during both the years of experimentation could be due to significant increase in number of branches plant ${ }^{-1}$ at harvest and increases in dry matter production plant ${ }^{-1}$ though these increments were not significant. Another reason for higher stover yield could be lower values of harvest index that had been recorded under early planting than normal planting. Relatively taller plants of rapeseed under early planting than normal planting might be attributed to the environmental factors such as temperature, soil moisture etc. that the crop availed due to advancement of planting time, but the effect did not persist till the maturity of the crop. Awasthi et al. (2007) also reported that highest plant height, length of siliqua, seeds siliqua ${ }^{-1}$, and seed and stover yields were obtained when the crop was sown on $15^{\text {th }}$ October than when it was sown on $30^{\text {th }}$ October. Early planting of rapeseed crop had resulted significant increase in seed oil content (38.5 and $36.9 \%$ ) than normal sown crop (37.4 and 33.7\%) (Table 2) because early planted crop experienced relatively lower average ambient temperature during seed setting period i.e. December, January, whereas mean ambient temperatures were higher during January and February, the period coinciding the seed setting period of normal sown crop. The increase in oil yield of rapeseed under early planting had been caused by increased seed yield as well as seed oil content. Hunsigi and Krishna (1998) noted that seed oil content of rapeseed was highest at ambient temperature of $10^{\circ}$ to $15^{\circ} \mathrm{C}$. Rana (2002) also revealed that delayed sowing of Brassica spp. caused significant reduction in yield attributes, oil content in seed, oil and biological yield. Early planting of the crop had resulted higher removal of all the major nutrients i.e. $\mathrm{N}, \mathrm{P}$ and $\mathrm{K}$ as a resultant effect of increased seed and stover yields and higher concentration of N, P and $\mathrm{K}$ in seed and stover in some cases. The findings are in agreement with Rana (2002).

\subsection{Effect of planting time on the performance of rice- rapeseed cropping system}

Advancement of rice planting by 15 days had resulted advancement of sowing time of rabi rapeseed crop in the sequence for a similar period. Because of this advancement of planting time, the system productivity in terms of rice equivalent yield (REY) was increased significantly (14\%) (Table 3). This was simply because of positive effect of early planting on all the component crops in the sequence. Early planting time occupied the land for longer duration and recorded higher resource use efficiencies in terms of land use efficiency (61.4\%)and production efficiency $\left(29 \mathrm{~kg} \mathrm{ha}^{-1}\right.$ day $\left.^{-1}\right)$ compared to normal planting. Since early planted crops in the system yielded higher than normal planted crop with same level of water and nutrient uses, early planting resulted in achieving significant improved values of WUE, PFP, NUE, PUE and KUE than normal planting. Hence, early planting could be noted superior in terms of water and nutrients use under the moisture stress situation.

\subsection{Effect of tillage practices on rapeseed}

The seed yield of rapeseed was lower under no tillage (NT) than conventional tillage (CT) during both the years, though it was significant in second year only. These findings could be supported by the observations on yield attributes such as number of siliquae plant ${ }^{-1}$, number of seeds siliqua ${ }^{-1}$ and 1000 seed weight which were mostly remained higher, sometimes even significant under conventional tillage practice (Table 1). These findings confirmed results of Chaudhary et al. (1991) who reported higher wheat grain yield in conventional tillage and deep tillage in comparison to no till. Chitale et al. (2007) also reported that conventional tillage in wheat produced $19.1 \%$ higher grain yield than zero tillage wheat. Sarma and Gautam (2010) also observed significant improvement in yield attributes (number of effective plants, grains $\mathrm{cob}^{-1}$, shelling \% and test weight) grain yield and biological yield due to tillage operation as compared to no-tillage. No tillage practice, though favoured plant height to some extent, but did not improve branches plant ${ }^{-1}$ and plant dry weight consistently throughout the growth period and between the years. With an obvious cause and effect relationship, the stover yield was significantly higher under conventional tillage practice. The harvest indices of rapeseed remained at par under two tillage systems. Mishra et al. (2005) reported that plant height of wheat was significantly higher under zero tillage than minimum and deep tillage. Seed oil content and oil yield also remained unaffected due to tillage practices treatments. The removals of nitrogen and phosphorus by the crop had been significantly higher under conventional tillage in the year 2011-12 (Table 2). This might be due to the fact that second year received good winter rains and a favourable environment was created for better growth of the crop which had resulted higher nutrients like $\mathrm{N}$ and $\mathrm{P}$ 
Table 3: Resource use efficiencies, rice equivalent yield (REY) and profitability of rice-rapeseed cropping system as influenced by liming and planting time to rice and tillage practices to rapeseed (pooled data of 2 years)

\begin{tabular}{|c|c|c|c|c|c|c|c|c|c|c|c|}
\hline \multirow[t]{2}{*}{ Treatment } & \multirow[t]{2}{*}{$\begin{array}{l}\text { LUE } \\
(\%)\end{array}$} & \multirow[t]{2}{*}{$\begin{array}{l}\text { PE }\left(\mathrm{kg}^{-1}\right. \\
\left.\mathrm{ha}^{-1} \text { day }\right)\end{array}$} & \multicolumn{3}{|c|}{$\begin{array}{l}\text { NUE (kg REY ha }{ }^{-1} \\
\text { applied) }\end{array}$} & \multirow[t]{2}{*}{$\begin{array}{l}\text { WUE (kg } \\
\left.\text { ha }^{-1} \mathrm{~mm}\right)\end{array}$} & \multirow[t]{2}{*}{$\begin{array}{l}\text { PFP }\left(\text { kg grain }{ }^{-1}\right. \\
\quad \text { kg NPK })\end{array}$} & \multirow[t]{2}{*}{$\begin{array}{l}\text { REY } \\
\left(\mathrm{t} \mathrm{ha}^{-1}\right)\end{array}$} & \multirow[t]{2}{*}{$\begin{array}{l}\mathrm{COC} \\
\left(₹ \mathrm{ha}^{-1}\right)\end{array}$} & \multirow[t]{2}{*}{$\begin{array}{l}\text { NR } \\
\left(₹ \mathrm{ha}^{-1}\right)\end{array}$} & \multirow[t]{2}{*}{$\mathrm{BCR}$} \\
\hline & & & $\mathrm{N}$ & $\mathrm{P}$ & $\mathrm{K}$ & & & & & & \\
\hline \multicolumn{12}{|l|}{ Liming } \\
\hline No liming & 60.13 & 26.79 & 65.60 & 121.38 & 155.30 & 17.60 & 26.50 & 5.84 & 30800 & 36364 & 1.19 \\
\hline Liming & 60.13 & 28.76 & 70.39 & 130.18 & 166.51 & 19.55 & 28.40 & 6.27 & 35299 & 36799 & 1.05 \\
\hline $\mathrm{SEm} \pm$ & & 0.54 & 1.32 & 2.47 & 3.17 & 0.48 & 0.67 & 0.12 & & 1346.9 & 0.04 \\
\hline $\mathrm{CD}(p=0.05)$ & & 1.86 & 4.56 & 8.53 & 10.95 & 1.66 & NS & 0.41 & & 4660.1 & 0.14 \\
\hline \multicolumn{12}{|l|}{ Planting time } \\
\hline Early & 61.37 & 29.02 & 72.59 & 134.47 & 172.15 & 19.51 & 29.50 & 6.45 & 33049 & 41163 & 1.27 \\
\hline Normal & 58.90 & 26.52 & 63.40 & 117.10 & 149.66 & 17.64 & 25.40 & 5.66 & 33049 & 32000 & 0.98 \\
\hline $\mathrm{SEm} \pm$ & & 0.54 & 1.32 & 2.47 & 3.17 & 0.48 & 0.67 & 0.12 & & 1346.9 & 0.04 \\
\hline $\mathrm{CD}(p=0.05)$ & & 1.86 & 4.56 & 8.53 & 10.95 & 1.66 & 2.31 & 0.41 & & 4660.1 & 0.14 \\
\hline \multicolumn{12}{|l|}{ Tillage } \\
\hline $\mathrm{NT}^{\#}$ & 59.86 & 27.55 & 74.74 & 149.49 & 199.32 & 18.37 & 30.40 & 5.98 & 30529 & 38269 & 1.26 \\
\hline $\mathrm{CT}^{*}$ & 60.41 & 27.99 & 61.25 & 102.08 & 122.49 & 18.78 & 24.50 & 6.13 & 35570 & 34895 & 0.98 \\
\hline $\mathrm{SEm} \pm$ & & 0.17 & 0.42 & 0.93 & 1.35 & 0.06 & 0.12 & 0.04 & & 412.5 & 0.01 \\
\hline $\mathrm{CD}(p=0.05)$ & & NS & 1.37 & 3.03 & NS & 0.20 & 0.39 & 0.13 & & 1345 & 0.03 \\
\hline
\end{tabular}

${ }^{\#}$ NT: No tillage; ${ }^{*} \mathrm{CT}$ : Conventional tillage; LUE: Land use efficiency; PE: Production efficiency; NUE: Nutrient use efficiency; WUE: Water use efficiency; PFP: Partial factor productivity; COC: Cost of cultivation; NR: Net return; BCR: Benefit cost ratio

uptake by the crop. However, removals of potassium by the crop were significantly higher under conventional tillage than no tillage during both the years of the field experiments. The findings corroborate with the findings of Sarma and Gautam (2010) which reported significantly higher uptake of nitrogen, phosphorus and potassium in maize under tilled condition in comparison to no-tilled condition. Since $\mathrm{ET}_{\text {crop }}$ under no tillage and conventional tillage remained almost equal in both the years, the higher seed yield under conventional had also resulted higher WUE during both the years of the study. The lowest WUE (water use efficiency) in wheat was recorded by Parihar (2004) under zero tillage treatment due to lower grain yield than the other tillage treatments.

\subsection{Effect of tillage on the performance of rice-rapeseed} cropping system

On an average of two years, conventional tillage (CT) recorded significantly higher system productivity in terms of rice-equivalent yield (REY) and water use efficiency than no tillage (NT). However, NT was found to be superior to CT in terms of nutrient use efficiencies and PFP for nutrient use as it recoded significantly higher values of NUE, PUE and KUE and PFP over CT (Table 3). One reason for higher PFP under no tillage might be the lower dose of fertilizer nutrients received by the treatment.

\subsection{System energy dynamics}

Liming treatment used higher system energy input than no liming (Table 4). However, liming did not have pronounced influence on gross energy output, net energy output and energy use efficiency of the system but liming enhanced system energy productivity and energy intensity in economic terms. No difference in energy input requirement of the system due to different planting times was noted. System maximum total energy output $\left(185.31 \times 10^{3} \mathrm{MJ} \mathrm{ha}^{-1}\right)$ was produced under early planting and the least value $\left(164.17 \times 10^{3} \mathrm{MJ} \mathrm{ha}^{-1}\right)$ was observed under normal planting time. This might be due to higher grain and by products yields of both the component crops produced under early planting. Early planting emerged as the most efficient in energy use with highest energy productivity of 0.843 $\mathrm{kg} \mathrm{MJ}^{-1}$ and energy intensiveness of $5.66 \mathrm{Mj}^{₹^{-1}}$. The highest input energy $\left(17.29 \times 10^{3} \mathrm{MJ} \mathrm{ha}^{-1}\right)$ was consumed by CT and the lowest $\left(15.09 \times 10^{3} \mathrm{MJ} \mathrm{ha}^{-1}\right)$ was required by NT practices. Compared to NT, energy input of CT was higher by $14.6 \%$. This could be attributed to more tillage operations under CT during rabi crop season. Though gross energy output was more in CT, energy use efficiency was maximum under NT. This mainly owed to use of less energy input under NT. The results were similar to the findings of Jha et al. (2011). 


\subsection{System economics}

As far as economics are concerned, application of liming was found to be not a profitable business in terms of net return and benefit-cost ratio (Table 3) as liming recorded significantly higher amount of net return (₹ 36,798 ha-1) over no liming (₹ $36,364 \mathrm{ha}^{-1}$ ), but it was statistically at par with no liming.

Table 4: Energetics of rice-rapeseed cropping system as influenced by liming and planting time to rice and tillage practices to rapeseed (pooled data of 2 years)

\begin{tabular}{|c|c|c|c|c|c|c|c|}
\hline $\begin{array}{l}\text { Treat- } \\
\text { ments }\end{array}$ & $\begin{array}{l}\text { Energy in- } \\
\text { put }\left(\times 10^{3}\right. \\
\left.\mathrm{MJ} \mathrm{ha}^{-1}\right)\end{array}$ & $\begin{array}{c}\text { Gross energy } \\
\text { output } \\
\left(\times 10^{3} \mathrm{MJ} \mathrm{ha}^{-1}\right)\end{array}$ & $\begin{array}{c}\text { Net energy } \\
\text { output } \\
\left(\times 10^{3} \mathrm{MJ} \mathrm{ha}^{-1}\right)\end{array}$ & $\begin{array}{l}\text { Energy-use } \\
\text { efficiency } \\
(\%)\end{array}$ & $\begin{array}{c}\text { Energy } \\
\text { productivi- } \\
\text { ty }\left(\mathrm{kg}^{-1} \mathrm{MJ}\right)\end{array}$ & $\begin{array}{c}\text { Energy intensity } \\
\text { in physical terms } \\
\left(\mathrm{MJ}^{-1} \mathrm{~kg}\right)\end{array}$ & $\begin{array}{l}\text { Energy intensity } \\
\text { in economic terms } \\
\left(\mathrm{MJ}^{-1} ₹\right)\end{array}$ \\
\hline \multicolumn{8}{|l|}{ Liming } \\
\hline No liming & 16.03 & 169.10 & 153.07 & 10.72 & 0.774 & 1.32 & 5.52 \\
\hline Liming & 16.36 & 180.37 & 164.02 & 11.13 & 0.803 & 1.26 & 5.13 \\
\hline $\mathrm{SEm} \pm$ & & 3.58 & 3.58 & 0.23 & 0.016 & 0.03 & 0.11 \\
\hline $\begin{array}{l}\mathrm{CD} \\
(p=0.05)\end{array}$ & & NS & NS & NS & 0.055 & NS & 0.38 \\
\hline \multicolumn{8}{|c|}{ Planting Time } \\
\hline Early & 16.19 & 185.31 & 169.12 & 11.61 & 0.837 & 1.21 & 5.66 \\
\hline Normal & 16.19 & 164.17 & 147.98 & 10.25 & 0.740 & 1.37 & 5.00 \\
\hline $\mathrm{SEm} \pm$ & & 3.58 & 3.58 & 0.23 & 0.016 & 0.03 & 0.11 \\
\hline $\begin{array}{l}\mathrm{CD} \\
(p=0.05)\end{array}$ & & 12.36 & 12.36 & 0.79 & 0.06 & 0.10 & 0.38 \\
\hline \multicolumn{8}{|l|}{ Tillage } \\
\hline $\mathrm{NT}^{\#}$ & 15.09 & 173.04 & 157.95 & 11.65 & 0.843 & 1.22 & 5.69 \\
\hline $\mathrm{CT}^{*}$ & 17.29 & 176.43 & 159.14 & 10.21 & 0.735 & 1.37 & 4.97 \\
\hline $\operatorname{SEm} \pm$ & & 0.50 & 0.50 & 0.03 & 0.002 & 0.01 & 0.01 \\
\hline $\begin{array}{l}\mathrm{CD} \\
(p=0.05)\end{array}$ & & 1.63 & NS & 0.10 & 0.01 & 0.03 & 0.03 \\
\hline
\end{tabular}

Moreover, it failed to record even higher $\mathrm{B}: \mathrm{C}$ ratio than no liming. High cost incurred by purchasing liming materials and its application and not so much impressive increase in yield due to liming made the treatment non-remunerative. The early planting was also found to be more remunerative as it was evident from higher amount of net return ( $₹ 41,162 \mathrm{ha}^{-1}$ ) along with higher B:C ratio (1.27) than normal planting. NT also recorded significantly higher net return ( $₹ 38,268 \mathrm{ha}^{-1}$ ) and B:C ratio (1.26) over $\mathrm{CT}$ as less cost of cultivation was incurred.

\subsection{Interaction effects}

The interaction effects between planting time and tillage on REY, net return and energy productivity of the cropping system were found significant. Performance of tillage practices on REYwas at par under early planting, whereas, conventional tillage was found significantly superior to no tillage under normal planting time.The highest REY of $6.47 \mathrm{t} \mathrm{ha}^{-1}$ (Table $4 a)$ recorded from early planted crops coupled with no tillage practices could be attributed to the same effect on the seed yield of both the crops. The maximum significant net returns
Table 4a: Interaction effect of planting time and tillage practices on REY $\left(\mathrm{t} \mathrm{ha}^{-1}\right)$ of rice-rapeseed cropping system (pooled data of 2 years)

\begin{tabular}{lccc}
\hline Planting time & NT & CT \\
\hline Early & 6.47 & & 6.43 \\
Normal & 5.50 & & 5.82 \\
SEm \pm & & 0.05 & \\
CD $(p=0.05)$ & & 0.16 & \\
\hline
\end{tabular}

Table 4b: Interaction effect of planting time and tillage practices on net return $\left(₹ \mathrm{ha}^{-1}\right)$ of rice-rapeseed cropping system(pooled data of 2 years)

\begin{tabular}{lcc}
\hline Planting time & NT & CT \\
\hline Early & 43921.3 & 38404.5 \\
Normal & 32615.8 & 31384.6 \\
SEm \pm & & 583.3 \\
CD $(p=0.05)$ & \multicolumn{3}{c}{1902.4} \\
\hline
\end{tabular}


Table 4c: Interaction effect of planting time and tillage practices on energy productivity $\left(\mathrm{kg}^{-1} \mathrm{MJ}\right)$ of rice-rapeseed cropping system (pooled data of 2 years)

\begin{tabular}{lccc}
\hline Planting time & NT & CT \\
\hline Early & 0.895 & & 0.780 \\
Normal & 0.79 & & 0.69 \\
SEm \pm & & 0.002 & \\
CD $(p=0.05)$ & & 0.008 & \\
\hline
\end{tabular}

of the system was realised when rice crop was planted early followed by no tillage rapeseed crop (E 43,921 ha-1) (Table $4 b)$. Similarly, the highest system energy productivity $(0.89$ $\mathrm{kg}^{-1} \mathrm{MJ}$ ) was obtained from early planting of rice coupled with no tillage practices on rapeseed (Table $4 \mathrm{c}$ ).

\section{Conclusion}

Liming@ $900 \mathrm{~kg} \mathrm{CaCO}_{3} \mathrm{ha}^{-1}$ is not profitable but improved system productivity after two years of crop cycle in ricerapeseed cropping system. Advancing the planting time of rice from first week of July to middle of June enhanced productivity, profitability and resource use efficiency of the system. Conventional tillage recorded higher yield than no tillage, but no tillage recorded higher net return and energy productivity over conventional tillage. In conclusion, combined application of liming, conservation tillage and early rice planting is recommended as a viable strategy for improving productivity, profitability and resource use efficiency of ricerapeseed cropping system.

\section{References}

Awasthi, U.D., Singh, R.B., Dubey, S.D., 2007. Effect of sowing date and moisture conservation practice on growth and yield of Indian mustard (Brassica juncea) varieties. Indian Journal of Agronomy 52(2), 151-153.

Bishnoi, S.K., 1994. Availability of native N and its uptake by soybean in acid soils of Himachal Pradesh as affected by liming. Bulletin of Indian Society of Soil Science 3, 255-262.

Chaudhary, M.R., Khera, R., Singh, C.J., 1991. Tillage and irrigation effects on root growth, soil water depletion and yield of wheat following rice. The Journal of Agricultural Science 116 (1), 9-16.

Chitale, S., Pandey, N. Urkurkar, J.S., 2007. Effect of planting method, tillage and weed management on productivity and physic-chemical properties of rice (Oryza sativa)wheat (Triticum aestivum) cropping system. Indian Journal of Agronomy 52(4), 283-288.

Datta, M., Gupta, R.K., 1984. Studies on P, Ca, Zn, Fe contents in soil and plant tissue as influenced by pressmud and lime. Journal of Indian Society of Soil Science 32, 450-458.

Ghosh, B.N. , Mukhopadhyay, A.K., 2001. Effect of liming on potassium release in a Oxic Paleustalf. Annals of Agricultural Research News Series 22(3), 377-381.

Gupta, J.P., Sharma, P.K., 1985. Changes in soil pH at different growth stages in late sown wheat as influenced by phosphorus, lime and organic matter in an acid Himalayan soil. Research and Development Reporter $2,4-8$.

Hunsigi, G., Krishna, K.R.,1998. Science of Field Crop Production. Oxford and IBH, New Delhi.

Jha, A.K., Kewat, M.L., Upadhyay, V.B., Vishwakarma, S.K., 2011. Effect of tillage and sowing methods on productivity, economics and energetic of rice (Oryza sativa)-wheat (Triticum aestivum) cropping system. Indian Journal of Agronomy 56(1), 35-50.

Kar, G., Singh, R., Verma, H.N., 2004. Productive and profitable management of rainfed lowland rice through intensive cropping and efficient water use. WTCER, Bhubaneswar. Research Bulletin 17, 56.

Kumpawat, B.S., 2001. Production potential and economics of different crop sequences. Indian Journal of Agronomy 46(3), 421-424.

Mahata, K.R., Sen, H.S., Pradhan, S.K., 1992. Tillage effects on growth and yield of blackgram and cowpea after wet season rice on an alluvial sandy clay loam in eastern India. Field Crops Research11, 55-68.

Mishra, J.S.; Singh, V.P. , Yaduraju, N.T., 2005. Effect of tillage practices and herbicides on weed dynamics and yield of wheat (Triticum aestivum) under transplanted rice (Oryza sativa)-wheat system in Vertisols. Indian Journal of Agronomy 50(2), 106-109.

Mittal, V.K., Mittal. J.P., Dhawan, K.C., 1985. Research digest on energy requirements in Agriculture sector (1971-82). ICAR/AICRP/ERAS/85 (1), Ludhiana, 159-163.

Parihar, S.S., 2004. Effect of crop-establishment method, tillage, irrigation and nitrogen on production potential of rice (Oryza sativa)-wheat (Triticum aestivum) cropping system. Indian Journal of Agronomy, 49(1), 1-5.

Patel, K.A.; Parmar, M.T., Patel, J.C., 1980. Effect of different sowing dates, spacing and plant population on yield of mustard. Indian Journal of Agronomy 25(3), 525-527.

Pratibha, G., Pillai, K.G., Satyanarayan, V., Hussain, M.M., 1996. Tillage systems for production of black gram (Vigna mungo) succeeding rice crops. Legume Research 19(1), 23-28.

Rana, D.S., 2002. Yield and yield attributes, nutrient uptake, nitrogen-use efficiency and economics of oliferous 
brassicas as influenced by time of sowing and fertility levels. Indian Journal of Agricultural Sciences 72(9), 519-524.

Raskar, B.S., Bhoi, P.G., 2001. Production and economics of winter sorghum (Sorghum bicolor)-summer vegetables cropping sequences under irrigated conditions of Western Maharashtra. Indian Journal of Agronomy 46(1), 17-22.

Raychaudhuri, M., Kumar, K., 2002. Direct and residual effects of lime on soil characteristics, yield and nutrient uptake of maize (Zea mays) and soybean (Glycine max) in an acid hill soil of Manipur. Indian Journal of Agricultural Sciences 72(2), 67-69.

Sarma, C.K. and Gautam, R.C., 2010. Weed growth, yield and nutrient uptake in maize (Zea mays) as influenced by tillage, seed rate and weed control method. Indian Journal of Agronomy 55(4), 299-303.

Syarifuddin, A.K., 1979. Establishment and performance of rainfed maize (Zea mays L.) and soybean (Glycine max (L) Merill) in the dry season after puddled rice. $\mathrm{PhD}$ thesis, UPLB Philippines, 354

Tomar, J.M.S., Das, A., 2011. Influence of trees leaf green manuring on low land rice (Oryza sativa L.) productivity in mid-altitudes of Meghalaya. Indian Journal of Soil Conservation 39(2), 167-170.

Tripathi, S.C., Singh, R.P., 2008. Effect of crop diversification on productivity and profitability of rice (Oryza sativa)wheat (Triticum aestivum) cropping system. Indian Journal of Agronomy 53(1), 27-31.

Yadav, R.N.; Bhan, S., Uttam, S.K., 1994. Effect of sowing date, variety and plant population on growth and yield of rainfed Indian mustard (Brassica juncea). Indian Journal of Agronomy 39(4), 682-684.

Yadav, G. S., Datta, M., Babu, Subhash, Debnath, C., Sarkar, P K., 2013. Growth and productivity of low land rice as influenced by substitution of nitrogen fertilizer through organic sources. Indian Journal of Agricultural Sciences 83(10), 1038-1042. 